\title{
Two Mode DPM Equipped with an Automatic Leak Test Using MPX5050GP and MPXV4115VC6U Sensors
}

\author{
Fita Florensa Rooswita ${ }^{1}$, Triana Rahmawati ${ }^{1}$, and Syaifudin ${ }^{1}$ \\ ${ }^{1}$ Department of Medical Electronics Engineering Technology, Poltekkes Kemenkes Surabaya, Jl. Pucang Jajar Timur No. 10, Surabaya, 60245, Indonesia, \\ Corresponding author: Triana Rahmawati (triana@poltekkesdepkes-sby.ac.id)
}

\begin{abstract}
The calibration process aims to guarantee measurement results in accordance with established standards. One of the tools used for pressure calibration is the Digital Presure Meter, which is the function of this tool to measure pressure on the Sphygmomanometer and Suction Pump or other tools that use pressure parameters for measurement. This module uses the Arduino system as a control and processing of analog data into digital data in order to condition the output of the MPX5050GP sensor for positive pressure and MPXV4115VC6U sensor for vacum pressure, this module uses a 4x20 LCD character display and there is a selection of $\mathrm{mmHg}$ and $\mathrm{Kpa}$ units with fluctuating resolution 0.25 . Also in this module there is also an automatic leak test feature for the Sphygmomanometer, the measurement results obtained an average error of $7.3 \mathrm{mmHg}$ for sphymomanometer measurements, and for suction pumps less than $1.5 \mathrm{Kpa}$. From these results it was concluded that this module can be used for the measurement of tools that use positive pressure and negative pressure.
\end{abstract}

INDEX TERMS Digital pressure meter, Sphygmomanometer, Arduino, MPX5050GP

\section{INTRODUCTION}

Sphygmomanometers has several observer error variables and devices used, which make measurement error problems and become a discussion in the midst of public health [1][2][3]. Discussions such as the correct method, the most common errors, the size and the proportion of fixed cuffs in the search for more reliable measuring devices that show patients' true blood pressure [4]. The results of blood pressure measurements carried out with mercury are different from the results of measurements made with a digital sphygmomanometer. With differences in measurement results it is necessary to identify blood pressure gauges. The results of blood pressure measurements must be done correctly, this is because of health concerns and patient safety. Errors in blood pressure measurement can be caused by human error or the function of the device itself whose accuracy has exceeded the allowable threshold (Standard error of up to 3 $\mathrm{mmHg}$ ) [5]. The maximum error permitted for blood pressure measurements anywhere on the scale range should be $\pm 0.4 \mathrm{kPa}$ $( \pm 3 \mathrm{mmHg})$ in the case of first time verification and $\pm 0.5 \mathrm{kPa}$ ( $\pm 4 \mathrm{mmHg}$ ) for the Sphymomanometer used [6][7].
The design of this DPM has been carried out by several previous researchers, Junia Dyah Permata Wibisono in 2017 made this module but only with one mode, namely vacuum pressure [8]. Then in 2018 Yosep Kurniawan made a two-mode DPM module but the weakness of this module lies in the measurement unit only one parameter, the use of the same negative sensor MPXV4115 but the difference in positive pressure [9]. Then in 2019 there were two people who made the DPM module namely Ryan Nur Rokhman and Abdul Cholid who made the same DPM in two modes and still used one measurement parameter, $\mathrm{mmHg}$ [10] [11]. Inadequate sphygmomanometer treatment and calibration are common causes of systematic errors in blood pressure measurement. The only way to reduce systematic errors is to use correct measurement techniques and instruments that are well maintained and calibrated [3]. Suction Pump is a medical device that functions to suck out liquids that are not needed by the body in the operation process, such as blood, stomach contents, and so on. Then the liquid that is sucked is collected in a container. The working principle of the Suction Pump is that the motor will rotate along with the suction fan so that it can suck the fluid in the patient's body through the suction hose which is connected through a tube and filter [12] [13]. 
Based on what has been described, the researcher will add the measurement unit parameters into two, $\mathrm{mmHg}$ and $\mathrm{Kpa}$, and will add a leakage test automatically, because tensimeter calibration requires a leak test, because it is very important to know whether tensimeter is still feasible or not. In addition to the leak test there are 2 measurement times, namely 60 seconds and 5 minutes, this refers to Permenkes.

This research is composed of 5 parts, part 2 which contains a study of literature and methods of development, part 3 which contains the research methodology and the results obtained, part 4 which contains a discussion of what was done during the research, and the last section contains conclusions.

\section{MATERIALS AND METHODS}

\section{A. EXPERIMENTAL SETUP}

This study uses a sphygmomanometer and suction pump subject that has been calibrated and the data is taken once

\section{B. MATERIALS AND DEVICE}

In this study using MPX5050GP [4] sensor made by freescale semiconductor in texas america for positive pressure reading while for negative pressure reading using MPXV4115VC6U sensor made by motorola semiconcuctor product in USA, In both sensors an appropriate capacitor was added with the datasheet on the sensor. in processing the output of the sensor using ARDUINO NANO ATMega 328 on pins A1 and A2, before processing the output first goes to the buffer circuit, for the power supply in this module uses 2 lithium polymer batteries, and all results will be displayed on a $4 \times 20$ character LCD.

\section{EXPERIMENT}

In this study, researchers conducted a calibration of the shygmomanometer and suction pump using a module that has been made, namely two mode DPM with 2 units of measurement, namely $\mathrm{mmHg}$ and $\mathrm{Kpa}$ [14].

\section{THE DIAGRAM BLOCK}

When the ON / OFF button is pressed, the voltage from the battery will supply the microcontroller and pressure sensor so that the tool is ready to use. Then, the LCD screen displays the selection mode between positive pressure and negative pressure. When the Positive Pressure is working, the MPX5050GP sensor is active then the sensor output is forwarded to the buffer circuit and then processed by Arduino nano ATMega 328, just as if the negative pressure is working then the active sensor is MPXV4115VC6U then the sensor output is forwarded to the buffer circuit and processed on the buffer circuit Arduino nano ATMega 328, from all the results will be displayed on the character LCD (Fig. 1).

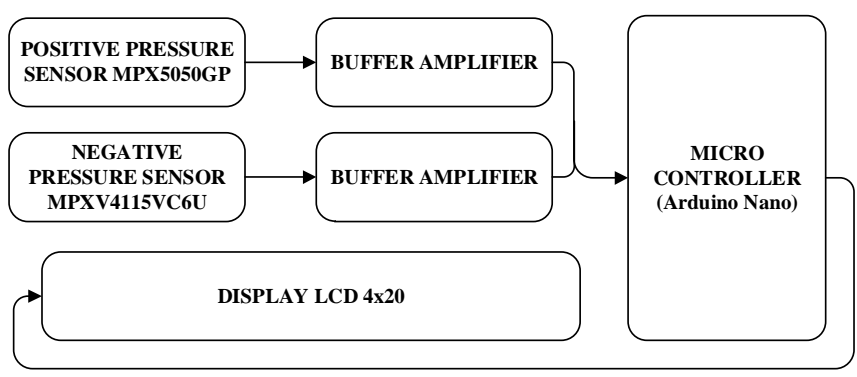

\section{E. THE FLOWCHART}

The flow chart shows the course of the program reading tool and the beginning to the end series. In this module there are two units of measurement, namely $\mathrm{mmHg}$ and $\mathrm{Kpa}$, there is also a selection of leak tests for the sphygmomanometer, after the selection is complete and push button enter is pressed then the sensor will start reading. The following is a flowchart of the module (Fig. 2).

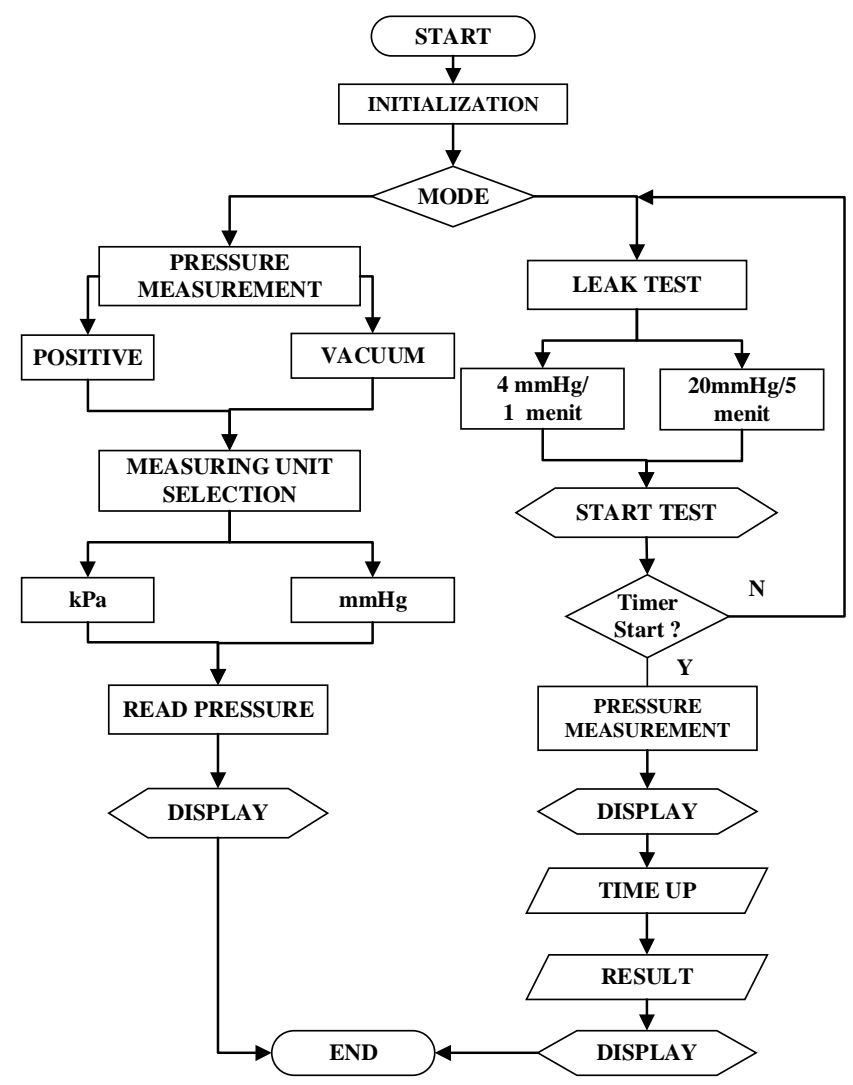

Fig 2. The Flowchart of the Arduino Program

\section{F. CIRCUIT}

1) Circuit of minimum system

Analog data from the sensor is converted to digital data by Arduino via PIN A0 (for positive pressure) and PIN A1 (for negative pressure). The $4 \times 20 \mathrm{LCD}$ is used to display the pressure data that has been taken. UP and DOWN selection buttons are used to select the desired pressure positive or negative pressure besides this button is also used for the selection of $\mathrm{mmHg}$ or Kpa units. When logic is high, the program will detect the presence of input on a digital pin and then the program will run a reading mechanism on the input pin variable which is processed in such a way that the equation is obtained so that a positive or negative pressure reading occurs. for the microcontroller testing step is done by running a simple program to check the push button function when not pressed and when pressed in accordance with the digital pins of each push button, and Configuring the initiation of the I2C converter program to set the $20 \mathrm{X} 4 \mathrm{LCD}$ display screen. (Fig. 3).

Fig 1. The diagram block of the Pulse Oximetry 


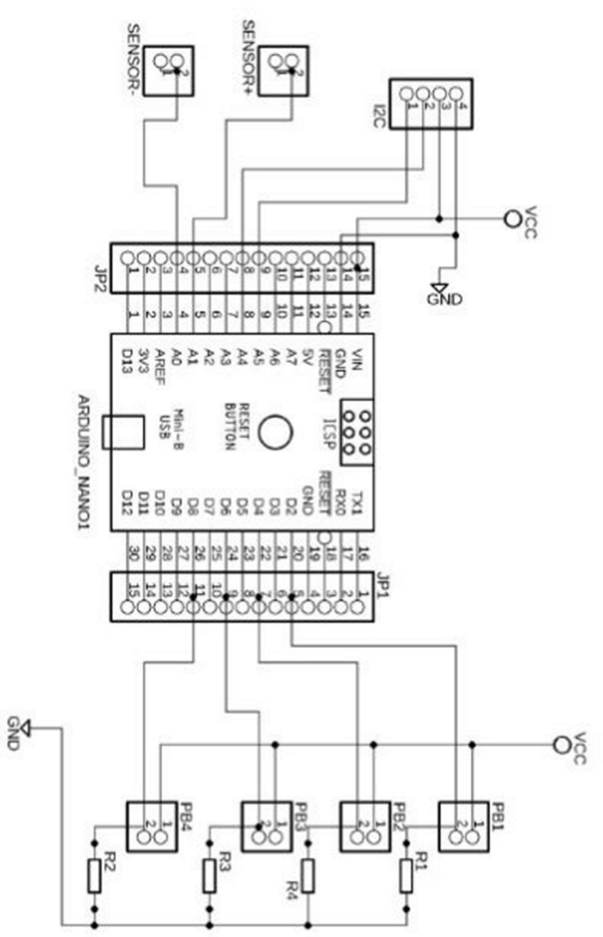

Fig 3. Circuit of minimum system

\section{2) Circuit of MPX5050GP}

Input in the sensor circuit is pressure, the pressure captured by the sensor will be converted to voltage. In this type of sensor the results of the ratio of pressure and voltage are directly proportional so that the resulting value is higher the pressure the higher the output results.

\section{3) Circuit of MPXV4115VC6U}

Input in the sensor circuit is pressure, the pressure captured by the sensor will be converted to voltage. In this type of sensor the results of the ratio of pressure and voltage are directly proportional so that the resulting value is higher the pressure the higher the output results.

\section{Results}

In this study using a sphygmomanometer and suction pump as a comparison and module parameters, and the units taken in this study are $\mathrm{mmHg}$ and $\mathrm{Kpa}$ for positive or negative pressure. The equipment need to be calibrated, so by making the module it can assist in the calibration of devices that use negative and positive pressure readings.

\section{A. DIGITAL PRESSURE METER DEVICE}

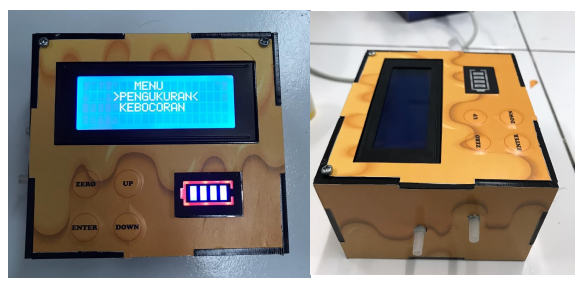

Fig 4. DPM display front and side views
A timer program using the system counter on millis (). With millis reading for 1000 times, a value of 1 second will be obtained and a reading of more than 60 seconds will produce 1 minute. The conditions in the last line are used to stop the timer.

\section{B. COMPARISON OF TWO DEVICES}

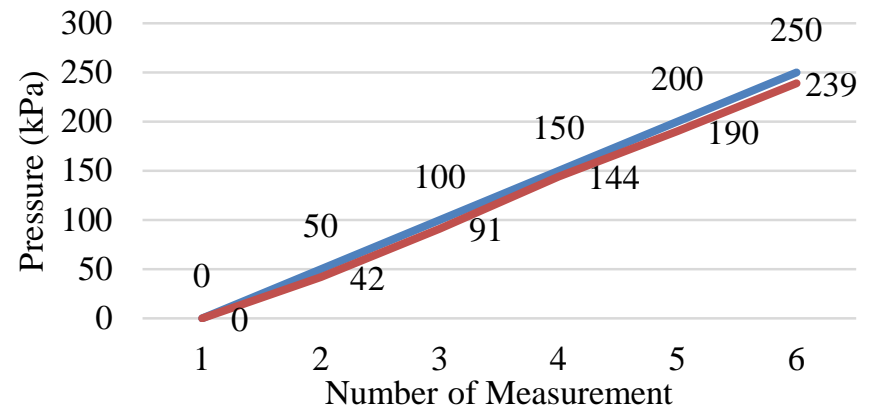

Fig 5. Measurement chart on the sphygmomanometer $(\mathrm{mmHg})$ (note: blue line is the setting pressure, and the red line is the measure pressure)

From Fig. 8 can be seen the measurement results of the sphygmomanometer using DPM modules with measuring ranges ranging from $0 \mathrm{mmHg}$ to $250 \mathrm{mmHg}$.

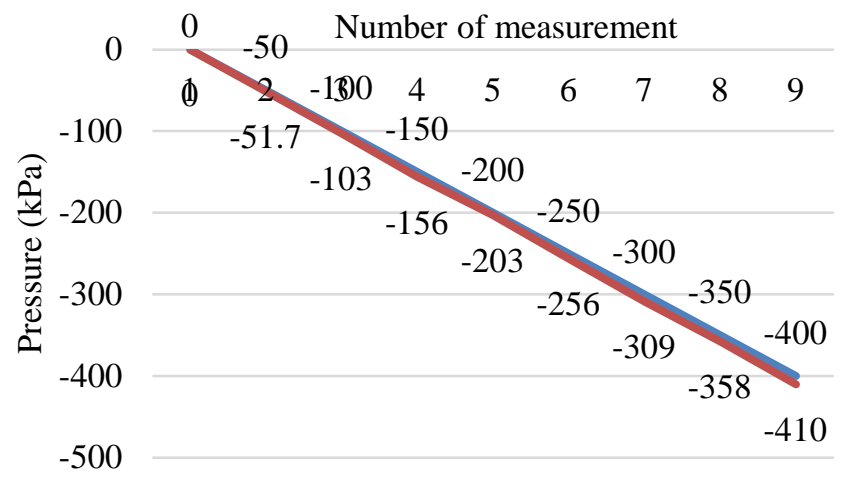

Fig 6. Measurement chart on the suction pump $(\mathrm{mmHg})$

From Fig. 9 can be seen the results of suction pump measurements using the DPM module with a measurement range from $0 \mathrm{mmHg}$ to $-400 \mathrm{mmHg}$.

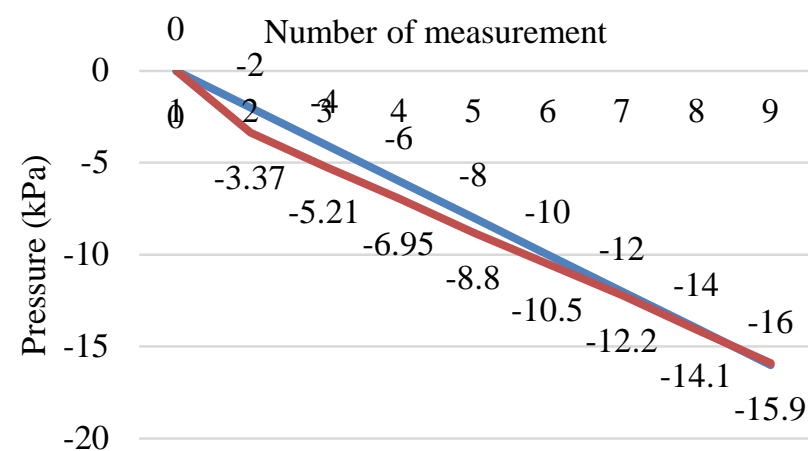

Fig 7. Measurement chart on the suction pump (Kpa)

From Fig. 10 can be seen the results of suction pump measurements using the DPM module with a measurement range from $0 \mathrm{Kpa}$ to $-400 \mathrm{Kpa}$. 


\section{DPM VS SPHYGMOMANOMETER (MMHG)}

TABLE 1 explains the measurements on the shygmomanometer and shows the results of the error in the form of $\mathrm{mmHg}$, and it can be seen that the higher the pressure reads, the greater the error.

TABLE I.

MEASUREMENT CHART ON THE SPHYGMOMANOMETER (MMHG)

\begin{tabular}{ccc}
\hline $\begin{array}{c}\text { Pressure } \\
(\mathrm{mmHg})\end{array}$ & $\begin{array}{c}\text { Measurement } \\
(\mathrm{mmHg})\end{array}$ & $\begin{array}{c}\text { Error } \\
(\mathrm{mmHg})\end{array}$ \\
\hline 0 & 0 & 0 \\
50 & 42 & 8 \\
100 & 91 & 9 \\
150 & 144 & 6 \\
200 & 190 & 10 \\
250 & 239 & 11 \\
\hline
\end{tabular}

\section{DPM VS SUCTION PUMP (MMHG)}

TABLE 2 describes the measurements on the suction pump and shows the results of an error in the form of $\mathrm{mmHg}$, here we can see that the resulting error is quite small.

TABLE I.

Measurement Chart On Suction Pump (Mmhg)

\begin{tabular}{ccc}
\hline $\begin{array}{c}\text { Pressure } \\
(\mathbf{m m H g})\end{array}$ & $\begin{array}{c}\text { Measurement } \\
\text { result }\end{array}$ & $\begin{array}{c}\text { Error } \\
(\mathbf{m m H g})\end{array}$ \\
\hline 0 & 0 & 0 \\
-50 & -51.7 & 1.7 \\
-100 & -103 & 3 \\
-150 & -156 & 6 \\
-200 & -203 & 3 \\
-250 & -256 & 6 \\
-300 & -309 & 9 \\
-350 & -358 & 8 \\
-400 & -410 & 10 \\
\hline
\end{tabular}

\section{E. DPM VS SUCTION PUMP (KPA)}

TABLE II.

Measurement chart on suction pump (Kpa)

\begin{tabular}{ccc}
\hline $\begin{array}{c}\text { Pressure } \\
(\mathbf{m m H g})\end{array}$ & $\begin{array}{c}\text { Measurement } \\
\text { result }\end{array}$ & $\begin{array}{c}\text { Error } \\
(\mathbf{m m H g})\end{array}$ \\
\hline 0 & 0 & 0 \\
-2 & -3.37 & 1.37 \\
-4 & -5.21 & 1.21 \\
-6 & -6.95 & 0.95 \\
-8 & -8.80 & 0.80 \\
-10 & -10.5 & 0.5 \\
-12 & -12.2 & 0.2 \\
-14 & -14.1 & 0.1 \\
-16 & -15.9 & 0.1 \\
\hline
\end{tabular}

TABLE 3 explains the measurements on the suction pump and shows the results of errors in the form of Kpa, here it can be seen that the smaller the negative pressure is read, the smaller the error obtained.

\section{Discussion}

In the DPM module that is made using positive and negative pressure measurements, this module has 2 units of measurement namely $\mathrm{mmHg}$ and $\mathrm{Kpa}$ for the measurement of the sphygmomanometer and suction pump. Then in 2019 there were two people who made the DPM module namely Ryan Nur Rokhman and Abdul Cholid who made the same DPM in two modes and still used one measurement parameter namely $\mathrm{mmHg}$, the difference between the two was in the display, the two were also not equipped with an automatic leak test used on the sphygmomanometer [15]. Therefore this research develops from previous studies using two $\mathrm{mmHg}$ and $\mathrm{Kpa}$ units and automatically adds leakage tests.the disadvantage of the module being made is that the power in the battery runs out quickly

\section{CONCLUSION}

The purpose of this study is to add two units of measurement namely $\mathrm{mmHg}$ and also Kpa and add automatic leak tests, and the use of the MPXV4115VC6U sensor as a negative pressure reading sensor is much better because it has a relatively small error tolerance. Overall this study can conclude that for positive pressure data taken only once and can be seen error values if averaged each measurement obtained a value of $7.3 \mathrm{mmHg}$. And for negative pressure with $\mathrm{mmHg}$ units the higher the value taken, the error generated on the tool is also greater. Whereas at the negative pressure the Kpa unit the higher the value taken the smaller the error produced. Due to the need for power in the DPM module that uses two sensors and also the LCD display is quite a lot, the suggestion for further research is the use of more battery power so that the use of the module can last a long time.

\section{REFERENCES}

[1] W. De Jong, P. Hartemann, and M. Thomsen, "Mercury Sphygmomanometers in Healthcare and the Feasibility of Alternatives," SCENIHR (Scientific Comm. Emerg. New. Identified Heal. Risks), no. September, 2009.

[2] P. Cristina Silva, R. Souza de Faria, A. Goncalves Sallum, L. Vinicius de Alcantara Sousa, V. E. Valenti, and P. Jose Oliveira Cortez, "Analysis of Mercury Sphygmomanometers in A Hospital School-Analysis of Mercury Sphygmomanometers," J. Cardiol. Ther., vol. 5, no. 1, pp. 697$700,2018$.

[3] S. Ghareeb et al., "Results of a project to calibrate mercury sphygmomanometer blood pressure-measuring devices in Egypt," $J$. Hum. Hypertens., 2020.

[4] A. J. Puspitasari, E. Endarko, and I. Fatimah, "Blood Pressure Monitor Design Using MPX5050GP Pressure Sensor and Visual C\# 2010 Express," J. Fis. dan Apl., vol. 15, no. 3, p. 99, 2019.

[5] K. D. Kusumadewi, "DPM Dua Mode Dilengkapi Thermohygrometer dan Pemilihan Tekanan (Positive Pressure)," Univ. Muhamhmadiyah Gersik, vol. 01, pp. 1-7, 2020

[6] V. A. Tsyrlin, M. G. Pliss, and N. V. Kuzmenko, "The history of blood pressure measurement: from Hales to our days," "Arterial'naya Gipertenz. ("Arterial Hypertens., vol. 22, no. 2, pp. 144-152, 2016.

[7] M. J. Turner, "Sphygmomanometer calibration Why, how and how often ?," no. November 2007, 2018.

[8] B. Mrozikiewicz-Rakowska, E. Bucior, J. Kania, A. Nowak, M Chojnowski, and J. Krzymień, "Modern alternative or first-line treatment: How to safely use Negative Pressure Wound Therapy in Diabetic Foot Syndrome?," Negat. Press. Wound Ther. J., vol. 2, no. 1, pp. 21-25, 2015.

[9] M. S. Timmers, S. Le Cessie, P. Banwell, and G. N. Jukema, "The effects 
of varying degrees of pressure delivered by negative-pressure wound therapy on skin perfusion," Ann. Plast. Surg., vol. 55, no. 6, pp. 665-671, 2005.

[10] I. E. Berliandhy, A. Rizal, S. Hadiyoso, and R. Febyarto, "A multiuser vital sign monitoring system using ZigBee wireless sensor network," ICCEREC 2016 - Int. Conf. Control. Electron. Renew. Energy, Commun. 2016, Conf. Proc., pp. 136-140, 2017.

[11] S. Sukaphat, S. Nanthachaiporn, K. Upphaccha, and P. Tantipatrakul, "Heart rate measurement on Android platform," in 2016 13th International Conference on Electrical Engineering/Electronics, Computer, Telecommunications and Information Technology, ECTI-CON 2016, 2016, no. 659, pp. 1-5.

[12] N. Thongpance and K. Roongprasert, "Design and construction of infusion device analyzer," BMEiCON 2014 - 7th Biomed. Eng. Int. Conf., 2014.

[13] N. Thongpance, Y. Pititeeraphab, and M. Ophasphanichayakul, "The design and construction of infusion pump calibrator," 5th 2012 Biomed. Eng. Int. Conf. BMEiCON 2012, vol. 100, pp. 3-5, 2012.

[14] F. Gaetani, P. Primiceri, G. A. Zappatore, and P. Visconti, "Hardware design and software development of a motion control and driving system for transradial prosthesis based on a wireless myoelectric armband," IET Sci. Meas. Technol., vol. 13, no. 3, pp. 354-362, 2019.

[15] M. R. Z. Fajar, S. Hadiyoso, and A. Rizal, "An interfacing digital blood pressure meter with arduino-GSM module for real-time monitoring," ICCREC 2017 - 2017 Int. Conf. Control. Electron. Renew. Energy, Commun. Proc., vol. 2017-Janua, no. September, pp. 98-102, 2017. 


\section{APPENDIX}

A. Program listing for positive pressure sensor readings

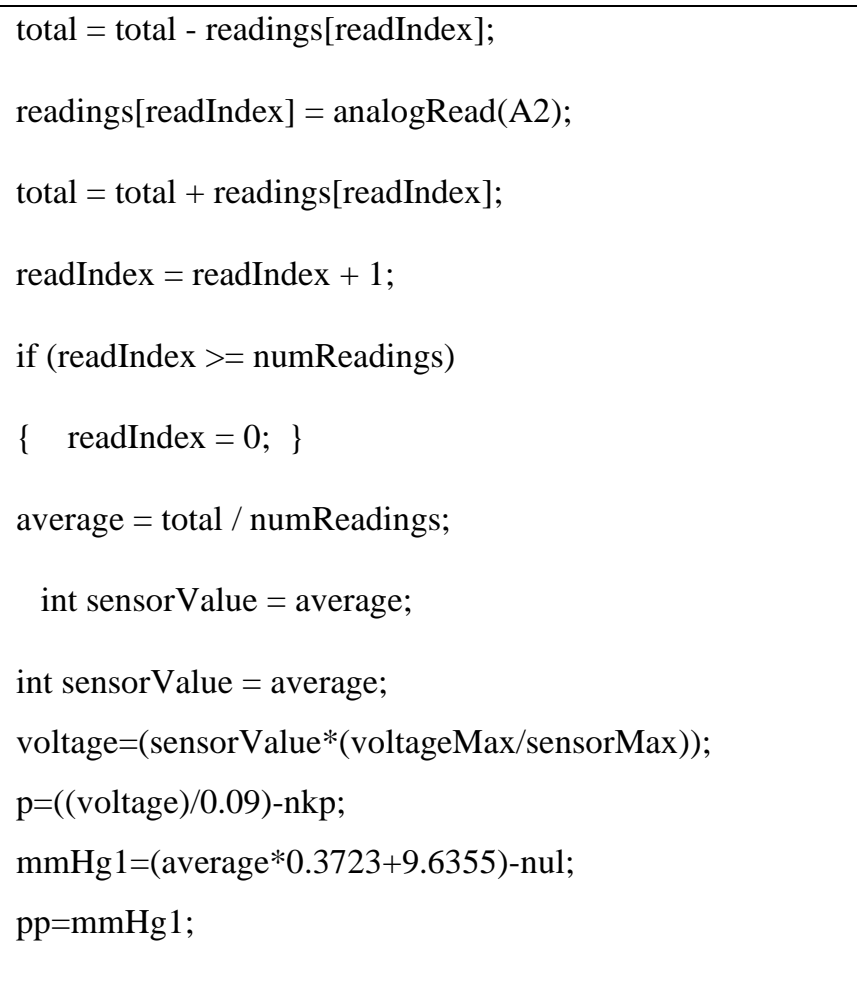

The above program functions as an initialization of a positive pressure reading on the MPX5050GP sensor from the microcontroller and also as an adc smooting program on the sensor with evenly distributed 10 adc reading data.

B. Progam listing for negaive pressure sensor readings

int sensorValue2 $=$ analogRead $(\mathrm{A} 0) ;$
voltage $2=($ sensorValue $2 *($ voltageMax/sensorMax $)$
p2=(((voltage $2-5.1) / 0.039)-10)-n k p 2 ;$
$\mathrm{mmHg} 2=(\mathrm{p} 2 * 7.50062)-n u 12 ;$
$\mathrm{np}=\mathrm{mmHg} 2 ;$

The above program is a program for TFT LCD and sensor inisiaisasi MAX30102 to be able to communicate with the microcontroller. TFT LCD with 9600 baudrate and sensor using a baudrate 115200 .

\section{Listing program for Display Menu}

menu:
while(1)
\{ lcd.setCursor(7, 0); //pengaturan tampilan
lcd.print("MENU");
lcd.setCursor(4, 1);
lcd.print(">PENGUKURAN<");
lcd.setCursor(5, 2);
lcd.print("KEBOCORAN");

sensor(); //pemanggilan void

waktu(),

delay( 200);

enter=digitalRead(2); //push button

up=digitalRead(4);

down=digitalRead $(6)$;

if(enter==HIGH) \{delay(200);lcd.clear();goto menupmp; $\}$

if(up==HIGH) $\{$ delay(200);lcd.clear();goto menukc; $\}$

if $($ down==HIGH $)\{$ delay(200);lcd.clear();goto menukc; $\}\}$

The menu program above there are various kinds according to needs and in the program created there are menus for each mode, namely a menu for measuring positive, negative, mmhg, Kpa, and leak tests.

D. Listing program for Timer

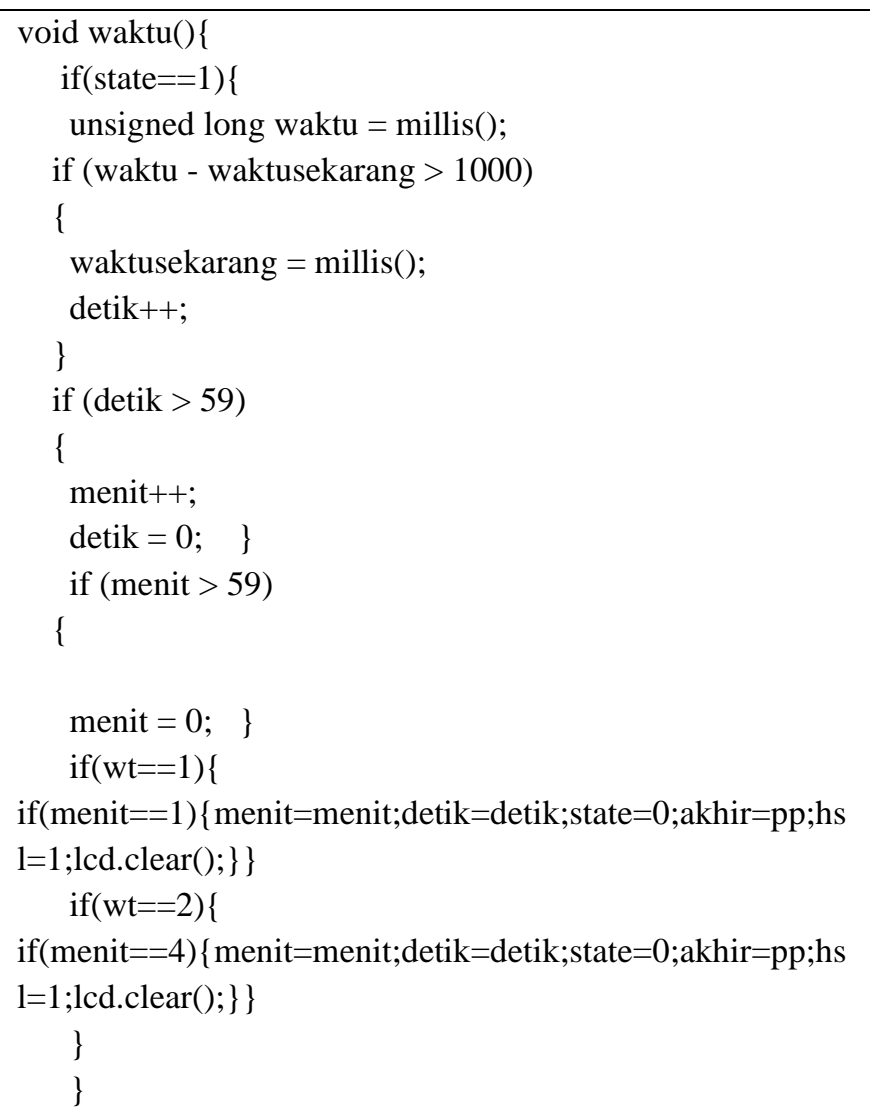

